\title{
The Manjanguak Tradition: Social Learning, Character Education and Psychological Effects
}

\author{
Dina Sukma ${ }^{*}$ \\ ${ }^{1}$ Universitas Negeri Padang \\ *Corresponding author e-mail: sukmadina@fip.unp.ac.id
}

\begin{abstract}
The "manjanguak" tradition is a series of funeral ceremonies held at the funeral home which is attended by family and relatives. The study of the manjanguak tradition is more concerned with the social values contained in it such as value of character education. This is because the manjanguak tradition is a tradition that exists in the human social realm that contains character education values. However, there has not been much discussion of its influence on the individual psychological aspects of this tradition. Humans are social creatures that are closely related to their environment. Humans who are detached from social ties will experience mental health problems such as low self-esteem and low self-control. Therefore, this article is a literature review that discusses all the dimensions contained in the manjangauak tradition. This article focuses not only on the social learning process and the values of character education, but also on the individual psychological effects of the manjanguak tradition.
\end{abstract}

Keywords: Manjanguak Tradition, Social Learning, Character Education, Individual Psychological

How to Cite: Sukma, D. (2020). The Manjanguak Tradition: Social Learning, Character Education and Psychological Effects. International Journal of Research in Counseling and Education, 4 (2): pp. 128134. DOI: http://doi.org/10.24036/00398za0002

\section{Introduction}

The "manjanguak" tradition is a tradition originating from the West Sumatra province of Indonesia in the form of a series of death ceremonies that are held at the funeral home at least fourteen days after death. In this tradition, members of the community come to the bereaved family without taking into account their kinship with the bereaved family, as long as they are recognized, the community will come with grasped of rice and a few eggs. In this tradition, all relatives are present, especially close relatives. Representatives of close relatives stay at the funeral home to help with all the necessities at the funeral home (Barone, Maddux, \& Snyder, 2012). These needs, such as cooking, looking after the house, and funeral home livestock, are not noticed by the family because they are grieving (Des \& Fitri, 2019).

The manjanguak tradition instills values of empathy, tolerance, and mutual cooperation. The values contained in this tradition are observed and absorbed by people who carry out the tradition, including children who are involved in the tradition. Through this tradition, adults do not have much to say about the theory of empathy and what tolerance is. The implementation of the manjanguak tradition will open up encouraging children to internalize various values which they then carry into their daily lives both in their family, school, peers and society, both now until they become adults (Des, Rizki, \& Hidayati, 2018).

Educational psychology is the development of a branch in psychology that studies how humans learn in an educational setting, the effectiveness of teaching, the learning process, and the organizational management of an educational institution (Naylor, Pritchard, \& Ilgen, 2013). Educational psychology applies psychological principles in a successful learning process, both pedagogical and andragogical. Therefore, this article will discuss the manjanguak tradition and its dimensions in terms of educational psychology.

\section{The Manjanguak Tradition}

Customs are rules or codes of conduct that are respected and obeyed by the community from generation to generation. Its function is to regulate society in order to create order in an area. Etymologically, the word adat itself comes from Arabic, namely "adah" which means way or habit. In this case, custom is defined as an act that is repeated so that it becomes a habit that must be obeyed by the community in an environment. Customs have several forming elements, namely cultural values that are considered important by society, a system of 
norms, a strict legal system, and special rules that are binding on society (Lee \& Tapp, 2010, Côté \& Levine, 2014).

Based on the form, customs can be divided into written and unwritten. Written custom usually takes the form of village upgrading. Then, unwritten customs can be in the form of traditional ceremonies such as the manjanguak tradition in West Sumatra. Although unwritten, customs still have a strong and binding influence on society. If someone violates, there will be sanctions as punishment (Fahmi \& Aswirna, 2014, Dewi, 2010). Usually, these sanctions take the form of social sanctions such as exclusion from society.

Manjanguak comes from the Minangkabau language, which is the language used by the tribes in West Sumatra, Indonesia. Another term that is often used with the same meaning is takziah. Manjanguak is visiting someone, friends, family, relatives, or colleagues who are grieving because a family member has died. Visiting relatives who are grieving because of what has been hit by a disaster is of course highly recommended in religion and in social life. This activity, which aims to establish friendship with people who are grieving, also aims to forgive each other.

Manjanguak is an unwritten custom that has a strong and binding influence on society. If there are members of the community who do not participate in the manjanguak tradition, there will be sanctions as punishment. The sanctions are in the form of social sanctions such as exclusion from society in the form that if the person concerned experiences grief, not so many other relatives will come.

\section{Series Activities of The Manjanguak Tradition}

In general, every time someone dies there will be a death ceremony in the form of a series of activities carried out in connection with the event of a person's death to show feelings of mourning (Des \& Fitri, 2019). The death ceremony is carried out in accordance with the customs and habits of the community concerned. The process of organizing death ceremonies in Minangkabau generally consists of bathing, dressing, burying, and praying for the body. After the death ceremony is carried out, the manjanguak tradition is followed as an expression of mourning. For the Minangkabau community, the implementation of the manjanguak tradition is a form of activity of community members that shows a sense of mourning for families who have suffered death (Des, Rizki, \& Hidayati, 2018, Des \& Fitri, 2019).

People who come, manjanguak have different activities seen from the things they bring to the funeral home. In these activities, there are activities that contain symbols, so that from these symbols can be seen the meaning of activities. manjanguak consists of two types, namely: manjanguak mantah and manjanguak cook. The manjanguak mantah tradition is a series of death ceremonies that are carried out at least fourteen days after death. Manjanguak mantah is the activity of visiting the funeral home with food ingredients in the form of rice, uncooked eggs and live chicken. The material is then carried in trays and delivered traditionally to the funeral home to be used by the bereaved. The manjanguak cooking tradition is the activity of bringing cooked food (ready to be served) in the form of rice, side dishes and lemang to the funeral home. After arriving at the funeral home, the food is handed over to the bereaved. Then the food is served to be eaten together. Before eating, first a group prayer is carried out aimed at the deceased, the bereaved family, and those who are present at the ceremony.

Manjanguak which is implemented by the Minangkabau community in West Sumatra has its own meaning. Its implementation begins with the community's interpretation of the practices or activities related to these traditions. In this modern era, generally people in West Sumatra prefer mantah manjanguak over cooking manjanguak because it is considered more practical. People go to Manjanguak with rice and eggs to give to grieving families shown in the Figure 1. The rice and eggs are carried using "kambuik". Kambuik is a small bag made from kumbuah or mensiang shown in the Figure 2. Why are the rice and eggs that are taken away when they go out? For people who go for Manjanguak, rice and eggs are very easy to get. Meanwhile, for the visiting family, these two food ingredients are very much needed, namely as a staple food and a side dish of protein sources. Eggs are very practical to cook in a few days when the family is grieving.

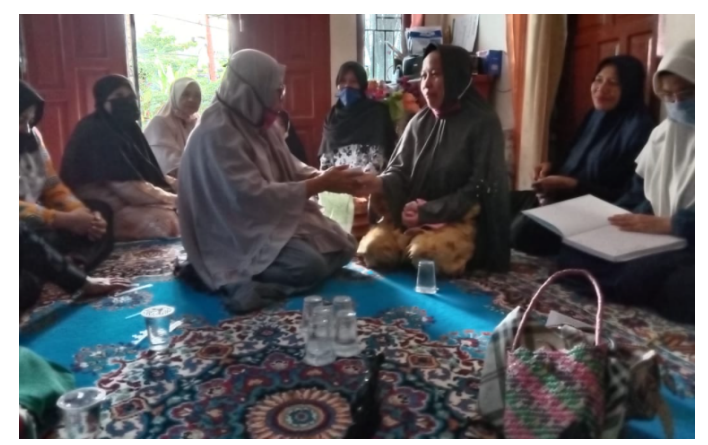

Figure 1. Manjanguak Activities 


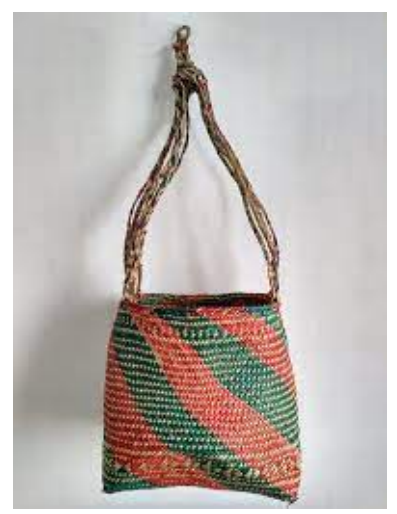

Figure 2. Kambuik to bring rice and eggs

\section{Social Learning on The Manjanguak Tradition}

Social learning is a synthesis of cognitive psychology and behaviorism that emphasizes personal and environmental cognitive abilities (Reed et al., 2010). On the one hand, both classical and operant conditioning of behaviorism explain behavior that is carried out through reinforcement of the environment (Rosenthal \& Zimmerman, 2014). On the other hand, theory mostly ignores the environment. So social learning theory combines the second concept by assuming that a person can learn by the behavior of others under certain environmental conditions (Shum \& Ferguson, 2012).

As social beings, humans are always in touch with other people. Through this interaction he experiences a learning process, because basically humans carry out learning activities throughout their life. Learning from the behavior of others, in Bandura's social learning theory, human behavior can be predicted and modified through learning principles by taking into account the thinking skills and interactions of people in their social environment (Barone, Maddux, \& Snyder, 2012). Humans are able to regulate themselves and control the environment, but actually humans are also shaped by their environment (Brandi \& Elkjaer, 2011).

The manjanguak tradition is behavior related to social behavior. This tradition makes individuals learn that they are members of their environment. Its existence in an environment that is recognized and well accepted will be interpreted as one's existence among the people in the environment. Even at the individual level, the formation of a person's identity is strongly influenced by the environment and culture in which he is located, through a process of adaptation and learning, both natural and constructed. Meanwhile, a person must build his existence as an individual or as part of a larger community, such as social, ethnic and cultural.

Existence is a reward that an individual receives as a reward for activeness in cultural activities. The existence of a person in the middle of the community is built through, among other things, a process of comparing with someone (or a number of people) and creating unique distinctions from each other, as stated that the person (individual) is the source of his existence (Ployhart, Nyberg, Reilly, \& Maltarich, 2014).

In the context of social learning, rewards function as information and as incentives for individuals to demonstrate behavior. A behavior will be deemed as expected and will be rewarded, or unsatisfactory and will be punished, depending on the personal standards used to evaluate the behavior. Thus, activities in the manjanguak tradition have provided internalization to individuals who are supported by the environment providing rewards in the form of social existence and acceptance of being in the middle of the environment and participating in every activity in the tradition.

\section{Moral Judgement on The Manjanguak Tradition}

The individual also studies the reinforcement obtained by the observed model and he can amplify himself. The behavior carried out by adults will set an example for children. A child will develop moral values based on the child's criteria based on intentions, irregularities, the amount of damage that will be generated and so on (Gini, Pozzoli, \& Hymel, 2014). Other things that are also important are the personal standards of a child, adult barriers, expected punishments or rewards and peer influence (Durkheim, 2012).

Moral judgment involves a complex process of considering various criteria in various social situations (Decety \& Cowell, 2014). It is argued that based on Bandura's social learning theory, behavior can be explained by the principle of reciprocal determinism. Where personal influences, environmental pressures and behavior itself function as mutually influencing determinants. The effect of each of these components is different for each person. According to Bandura, humans do not only react to the external environment, but external factors influence behavior by mediating one's cognitive processes (Bandura \& Hall, 2018).

The involvement of children in the manjanguak tradition is an effort to maintain the manjanguak tradition in the future. As they get older, children will grow into adolescents and then adults who will play an important 
role in the manjanguak process. Morals that are internalized by children based on their observations of adult behavior. Manjanguak is internalized as moral behavior as a form of empathy for the state of suffering that is being felt by others. Not participating on manjanguak behavior is internalized as behavior that lacks empathy or is immoral.

\section{The Value of Character Education on The Manjanguak Tradition}

The manjanguak tradition contains several character values that are instilled through a series of activities that are within the tradition. The value of character education that is very strong in the Manjanguak tradition is the value of caring for others. Helping in the tradition of manjanguak relatives and neighbors comes to help in preparation for the arrival of other relatives, because on manjanguak there are not a few who are sometimes fifty to one hundred people. When the execution of death is complete, they together clean up the places that have been used. In helping, there is a relationship of interdependence as a result of an exchange process that gives reciprocity or services given to him by others. Please help in the Minangkabau community in a series of manjanguak activities that occur spontaneously and on a voluntary basis, but some are based on mutual need that exists in the soul of the community. This helping activity is defined as a work activity that involves labor with the aim of helping families who are grieving and they do not receive compensation in the form of wages.

A characteristic feature of the Minangkabau people in West Sumatra in dealing with bereaved families is to bring items such as rice and eggs to be given to the family of the deceased or the deceased in the hope that they can help alleviate their suffering during the time of grieving. The majanguak tradition is a form of solidarity by a member of the community with relatives, members, coworkers or other members of the community who are grieving. The solidarity provided by the Minangkabau community is not only in matters of matter but includes affection, care and other kindness. In a sociological context, the manjanguak tradition is a tool to strengthen the social solidarity of the community.

Participating in a manjanguak event to gather and pray together is a social attitude that has the meaning of grieving the bereaved family for the tragedy that has befallen him, namely the death of a family member. Togetherness and unity will create harmony between both the old and the young. In the togetherness that exists, a sense of care and affection is shown to the bereaved family. This togetherness will spread to everyday life in society. A bereaved family who feels cared for and loved also wants to reciprocate by giving the same attention and affection to this relative in everyday life, especially when other relatives also experience the same situation. Then it will create an atmosphere of mutual care and affection between one another in a community environment.

\section{Self Control Effect on The Manjanguak Tradition}

Self-control is defined as the ability to organize, guide, regulate and direct forms of behavior that can lead to positive consequences (Cheung, Gillebaart, Kroese, \& De Ridder, 2014). Self-control is one of the potentials that can be developed and used by individuals during the process of life, including in dealing with conditions in the surrounding environment. Self-control is one of the personal competences that every individual needs to have (De Ridder, Lensvelt-Mulders, Finkenauer, Stok, \& Baumeister, 2012, Muraven, 2010). Good, constructive behavior, and harmony with others is influenced by the individual's ability to control himself (Duckworth, 2011). Individual behavior is determined by two variables, namely internal variables and external variables. No matter how strong the external stimuli and reinforcements, individual behavior can still be changed through the process of self-control. Even though external conditions are very influencing, with selfcontrol abilities, individuals can choose which behavior to display.

Self-control is related to how individuals control their emotions and impulses from within themselves. Selfcontrol, through cognitive, individuals can control themselves so that they can direct and organize themselves (Kotabe \& Hofmann, 2015). In observing other people, the environment and behavior can be managed according to their ability to interact. Self-control in the manjanguak tradition is practiced and necessary. The manjanguak tradition personally does not provide any benefits, on the contrary, it makes you tired, consumes time and energy, maybe even feels bored. In living the manjanguak tradition, every individual has the freedom to fulfill his desire to relax or have fun. In a narrow sense, self-control is related to controlling negative emotions so that their expression is not too explosive so that it has an impact on self and environmental chaos. So in undergoing the manjanguak tradition, the ability to control the id to continue to follow the tradition is a training process for self-control in a broad sense. On the other hand, people who do not participate in manjanguak activities by reason of being lazy or bored will make them become people who just follow what they like. A person who prioritizes pleasure has basically has low self-control.

\section{Self Esteem Effect on The Manjanguak Tradition}

Self-esteem is commonly known in everyday language, namely self-esteem or self-esteem. Self esteem is important in one's life. We as individuals cannot be separated from other individuals, because in essence 
humans are social creatures. In interacting it is appropriate for someone to respect other people or vice versa. However, in addition to respecting others, one also needs to respect himself. Self esteem is closely related to self concept. One of the advantages of humans is that humans can see about themselves. Self-esteem is a very important key to knowing someone's behavior. Self-esteem is a self-evaluation made by each individual; a person's attitude towards himself in the range of positive-negative dimensions.

The level of self-esteem of a child is influenced by three important components involved in the selfevaluation process, namely feedback from significant others; knowledge of who he is and his sense of identity, his values, belief in personal values; as well as awareness of the level of competence and appreciating their achievements (Orth \& Robins, 2014, McKay \& Fanning, 2016). In line with these components, there are several external factors that can influence children's self-esteem, namely family factors (both support and involvement of parents, parental warmth, expectations and consistency of parents, parenting, and modeling), gender, race, ethnicity, socio-economic status, and social values.

The rewards that individuals get from society as a consequence of their participation in the menganguak tradition are acceptance and recognition of the social environment. This recognition and acceptance will then make a person then assess their behavior in the context of standard norms or achievements in the related group. Self-esteem will increase accompanied by increased self-esteem. On the other hand, people who are not involved in manjanguak activities will be ostracized by the community. This rejection from society has an effect on how a person values himself. A person's low appreciation for himself will result in the person's low selfesteem.

\section{Dimensions on The Manjanguak Traditions}

The concepts of social learning theory that the individual's behavior is determined by the person and the environment (Naylor, Pritchard, \& Ilgen, 2013). However, the discussion in question is the opposite of social learning theory that the participation of individuals in the manjanguak tradition in the form of behavior associated with that tradition that has an influence on the personal of the individuals. This is explained in the Figure 3.

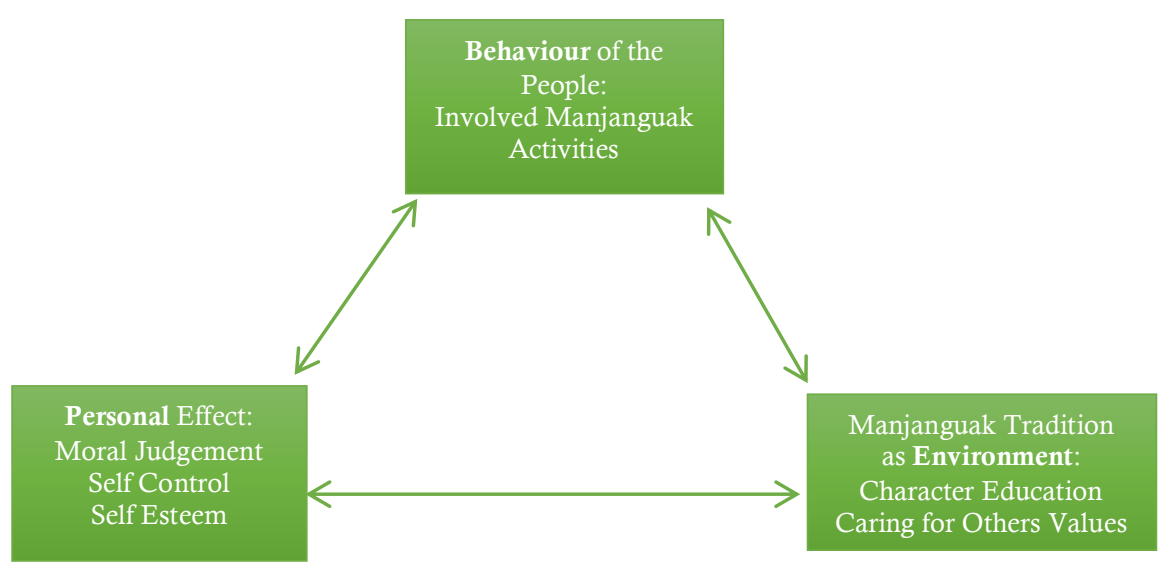

Figure 3. Dimensions of The Manjanguak Tradition

Social learning theory underlines the psychological mechanisms of self-systems and socio-structural factors. A person studies the behavior from observing the model in his/her environment, namely the manjanguak behavior by many people including himself who is in the middle of the crowd. Participation on manjanguak activities will give the individuals who attend the form of rewards and test their ability to selfcontrol so that they are not only concerned with their personal needs. Rewards that are obtained from the environment in the form of acceptance and linking will provide a feeling of worth to the individual in the form of increased self-esteem. In Figure 3 it can be seen that the manjanguak tradition is an environment that contains character education values, namely caring for others. Meanwhile, the activities of the people involved are carrying out the manjanguak series of activities. The series of activities and values contained in the manjanguak tradition have an effect on the personalities of the individuals involved, namely moral judgment, self-control and self-esteem. So it can be said that the manjanguak tradition has a complete and perfect educational psychology dimensions. The manjanguak tradition has the aim of education to instill the value of caring for others but it is an activity that has a noble purpose for human trafficking and the mental health of groups and individuals in it. 


\section{Conclusion}

The manjanguak tradition has noble human values. This tradition is beneficial for society, groups and individuals. For grieving, to be a consolation, for the cultural community to be the glue by cultivating the character values of caring for others. Besides that, the manjanguak tradition also affects the mental health of individuals, increases self-control and self-esteem. People who do not participate in manjanguak activities by reason of being lazy or bored will make them basically has low self-control and rejection from society has an effect on how a person values himself which then affect low self-esteem.

\section{References}

Bandura, A., \& Hall, P. (2018). Albert bandura and social learning theory. Learning Theories for Early Years Practice, 63.

Barone, D. F., Maddux, J. E., \& Snyder, C. R. (2012). Social cognitive psychology: History and current domains. Springer Science \& Business Media.

Brandi, U., \& Elkjaer, B. (2011). Organizational learning viewed from a social learning perspective. Handbook of Organizational Learning and Knowledge Management, 2, 23-41.

Cheung, T. T. L., Gillebaart, M., Kroese, F., \& De Ridder, D. (2014). Why are people with high self-control happier? The effect of trait self-control on happiness as mediated by regulatory focus. Frontiers in Psychology, 5, 722.

Côté, J. E., \& Levine, C. G. (2014). Identity, formation, agency, and culture: A social psychological synthesis. Psychology Press.

De Ridder, D. T. D., Lensvelt-Mulders, G., Finkenauer, C., Stok, F. M., \& Baumeister, R. F. (2012). Taking stock of self-control: A meta-analysis of how trait self-control relates to a wide range of behaviors. Personality and Social Psychology Review, 16(1), 76-99.

Decety, J., \& Cowell, J. M. (2014). The complex relation between morality and empathy. Trends in Cognitive Sciences, 18(7), 337-339.

Des, M., \& Fitri, M. (2019). Plants used in the traditional ceremony in kanagarian tiku. Journal of Physics: Conference Series, 13171), 12098. IOP Publishing.

Des, M., Rizki, R., \& Hidayati, H. (2018). Ethnobotany in Traditional Ceremony at Kanagarian Sontang Cubadak Padang Gelugur Subdistrict, Pasaman District. IOP Conference Series: Materials Science and Engineering, 335(1), 12018. IOP Publishing.

Dewi, S. F. (2010). Oral tradition in the study of ulayat land disputes in West Sumatra. Wacana, 12(1), 70-84.

Duckworth, A. L. (2011). The significance of self-control. Proceedings of the National Academy of Sciences, 108(7), 2639-2640.

Durkheim, E. (2012). Moral education. Courier Corporation.

Fahmi, R., \& Aswirna, P. (2014). The paradox of Islam and culture (tradition and belief abot gender perspective in West Sumatra). Buletin Al-Turas, 202), 313-324.

Gini, G., Pozzoli, T., \& Hymel, S. (2014). Moral disengagement among children and youth: A meta-analytic review of links to aggressive behavior. Aggressive Behavior, 4a1), 56-68.

Kotabe, H. P., \& Hofmann, W. (2015). On integrating the components of self-control. Perspectives on Psychological Science, 105), 618-638.

Lee, G. Y., \& Tapp, N. (2010). Culture and Customs of the Hmong. ABC-CLIO.

McKay, M., \& Fanning, P. (2016). Self-esteem: A proven program of cognitive techniques for assessing, improving, and maintaining your self-esteem. New Harbinger Publications.

Muraven, M. (2010). Building self-control strength: Practicing self-control leads to improved self-control performance. Journal of Experimental Social Psychology, 46(2), 465-468.

Naylor, J. C., Pritchard, R. D., \& Ilgen, D. R. (2013). A theory of behavior in organizations. Academic Press.

Orth, U., \& Robins, R. W. (2014). The development of self-esteem. Current Directions in Psychological Science, 23(5), 381-387.

Ployhart, R. E., Nyberg, A. J., Reilly, G., \& Maltarich, M. A. (2014). Human capital is dead; long live human capital resources! Journal of Management, 40(2), 371-398.

Reed, M. S., Evely, A. C., Cundill, G., Fazey, I., Glass, J., Laing, A., ... Raymond, C. (2010). What is social learning? Ecology and Society, 15(4). 
Rosenthal, T. L., \& Zimmerman, B. J. (2014). Social learning and cognition. Academic Press.

Shum, S. B., \& Ferguson, R. (2012). Social learning analytics. Journal of Educational Technology \& Society, 15(3), $3-26$. 